\title{
CORRELATION BETWEEN ENVIRONMENTAL FACTORS AND THE HUMAN DEVELOPMENT INDEX IN EAST JAVA IN 2019
}

\author{
Nadiyah Firdaus ${ }^{1}$, Airil Haimi Mohd Adnan ${ }^{2}$ \\ ${ }^{1}$ Faculty of Public Health, Universitas Airlangga, 60115 Surabaya, East Java, Indonesia \\ ${ }^{2}$ Universiti Teknologi MARA (UiTM), 40450 Shah Alam, State of Selangor, Malaysia \\ Corresponding Author: Nadiyah Firdaus \\ E-mail: nadiyah.firdaus-2016@fkm.unair.ac.id
}

\begin{abstract}
Public health is influenced by environmental factors. The success of public health development can be seen from the Human Development Index (HDI). This research aims to analyze the relationship between environmental factors and the HDI in East Java in 2019. This research analyzed secondary data obtained from the East Java Provincial Health Office and published on the website of the Central Bureau of Statistics. Health Profile data in 2018 and the Human Development Index data in 2019 were used. This study used total sampling and selected all districts/cities in East Java (38 districts/cities). The Shapiro Wilk test (a sample of less than 50) was chosen to analyze the normality of the data and a Pearson correlation test was conducted to investigate the relationship between each variable. Based on our Pearson correlation analysis, we found several relationships between each variable. This study found that there is a relationship between access to decent drinking water and the HDI, as well as qualified latrines with the HDI, both with p-values of 0.000 . Relationships were also found for healthy homes with the HDI with the p-value of 0.004 , as well as qualified public places with the HDI with the p-value of 0.003 . Finally, we found that there was no relationship between decent drinking water quality the HDI with a p-value of 0.821 .
\end{abstract}

Keywords: health, life expectancy, environmental factors

\begin{abstract}
ABSTRAK
Berhasil tidaknya pembangunan kesehatan masyarakat dapat dilihat dari Indeks Pembangunan Manusia (IPM). Salah satu indikator IPM adalah Angka Harapan Hidup (AHH) yang ada di masyarakat. Tinggi rendahnya derajat kesehatan masyarakat salah satunya dipengaruhi oleh faktor lingkungan. Penelitian ini bertujuan untuk menganalisis hubungan antara faktor lingkungan dengan Indeks Pembangunan Manusia yang ada di Provinsi Jawa Timur pada tahun 2019. Penelitian ini menggunakan analisis data sekunder dari Dinas Kesehatan Provinsi Jawa Timur yaitu berupa data Profil Kesehatan pada tahun 2018 dan publikasi website Badan Pusat Statistik berupa data Indeks Pembangunan Manusia pada tahun 2019. Penggunaan sampel dalam penelitian ini menggunakan total sampling seluruh kabupaten/kota yang ada di Jawa Timur (38 kabupaten/kota). Analisis yang digunakan dalam penelitian yaitu uji saphiro wilk (sampel kurang dari 50) untuk melihat normalitas data dan uji korelasi Pearson untuk melihat hubungan antar variabel. Berdasarkan analisis korelasi pearson, terdapat hubungan antara Akses Air Minum Layak dengan Indeks Pembangunan Manusia dengan p-value 0,000, Jamban yang Memenuhi Syarat dengan Indeks Pembangunan Manusia dengan p-value 0,000, Rumah Sehat dengan Indeks Pembangunan Manusia dengan p-value 0,004, Tempat-tempat Umum yang Memenuhi Syarat dengan Indeks Pembangunan Manusia dengan p-value 0,003, tidak terdapat hubungan antara Kualitas Air Minum yang Layak dengan Indeks Pembangunan Manusia dengan p-value 0,821. Hasil penelitian ini diharapkan dapat menjadi rekomendasi akan perlunya program yang efektif diantaranya yaitu program pelatihan filtrasi air layak minum dan program arisan jamban sehat dimana diperlukan adanya dukungan dan kerjasama lintas sektor khususnya dari Pemerintah Daerah dan PDAM setempat.
\end{abstract}

Kata kunci: kesehatan, angka harapan hidup, faktor lingkungan.

\section{INTRODUCTION}

Health is an important aspect of human life. According to Law No. 36 of 2009, a healthy individual is described as someone who is physically, mentally, spiritually, and socially sound, and allows everyone to be both socially and economically productive. In addition, health is an investment in human resources for a region and a nation, and it exerts a very strong influence on the Human Development Index (Dwiningtias and Maheasy, 2019). Therefore, to prevent and overcome disturbances caused by diseases or those that can interfere with health, it is necessary to continuously uplift health care efforts.

Changes in public health can be caused by behavioral factors, environmental health factors, heredity, and health services. As stated in a study by Zaraz, psychosomatic health well being or the degree of public health, is the result of four factors. They are the environment and behavior, both of which are related to ecological balance; the population, which is influenced by heredity and population distribution; and health 
care service, in the form of preventive, promotive, curative, and rehabilitative health programs. The requirements that must be fulfilled for a healthy individual are a long life, accompanied by a good life, as seen from the value of life expectancy (Yektiningsih, 2018).

In addition to the elements of teaching and competence in buying an item and supporting needs, aspects of health quality also need to be considered because they are important elements in human resource development. To improve the health of future generations in Indonesia, all activities carried out to maintain and protect the health status of the community would be better if they were based on the principles of nondiscrimination, participation, and sustainability (Devy et al., 2017).

To see the success rate of health development in a region, health indicators must be measured from the outset. One of the measuring tools that could be used is life expectancy. Life expectancy is one of the indicators of HDI because an increase in life expectancy indicates the success of socioeconomic development programs (Danasari and Wibowo, 2017). This is reinforced by research that states that if there is a decrease in life expectancy, it then has the potential to reduce the HDI (Zuhairoh and Melaniani, 2017). According to Statistics Indonesia, the cumulative period in which a newborn baby will live in a given year is known as Life Expectancy at birth (Sugiantari and Budiantara, 2013). Alternately, AHH describes the average age at death in a geographical area.

The life expectancy indicator could be used to determine the level of human development in an area (Sari, et al., 2016). The quality of life of residents in an area determines the difference in $\mathrm{AHH}$ within that area. A study found that the life expectancy in Bojonegoro Regency has shown an increase from year to year. In 2014, the AHH was 70.75 years and it has continued to increase until 2015 to 70.76 years. Then, in 2016 the life expectancy rate decreased to 70.11 years. However, in 2017, the AHH of Bojonegoro Regency increased rapidly and reached 70.83 years. Thus, the increase in life expectancy is a sign of improvement towards the quality of public health in Bojonegoro Regency (Siswati and Hermawati, 2018).

As aforementioned, four factors determine the degree of public health, including environmental factors, behavior, health services, and heredity. These four factors indirectly affect life expectancy (Blum, 1974). Environmental factors that can affect the degree of public health are related to the ownership of family latrines that meet certain requirements. Research has found that to improve the degree of public health, the existence of the family toilet as a basic sanitation facility is needed to maintain environmental health (Shahrir, et al., 2019).

In addition to latrines that meet requirements, healthy homes also improve the health status of the community. Suwita et al., (2019) found that the presence of Acute Respiratory Tract Infection (ARTIs) and tuberculosis can be caused by a home environment that does not meet health requirements and does not meet the hygienic standards of residential buildings.

Another environmental factor that can affect the health status of the community are public places that need to meet the requirements of good sanitation. Germs, viruses, and bacteria in the market sourced from trash cans can be transmitted from the environment to humans and then from one human to another, thus causing health problems (Putri et al., 2018). Therefore, this study focuses on the relationship between environmental factors and the HDI in East Java in 2019.

\section{METHODS}

The independent variables in this study were healthy homes, access to proper drinking water, decent drinking water quality, latrines that meet requirements, and public places that meet health requirements. The dependent variable was the HDI in East Java in 2019 (Central Bureau of Statistics, 2019).

This study used secondary data from the East Java Provincial Health Office and the publication of the Central Statistics Agency website. The raw data obtained was the 2018 Health Profile as the independent variable, and the 2019 HDI as the dependent variable. The sample used was all districts/cities in East Java Province with a total of 38 samples (i.e., total sampling). Bivariate Analysis with the Pearson Correlation Test was implemented to determine whether there is a correlation between several environmental factors and the HDI. Before using the Pearson correlation test, a normality test was conducted to see the type of data distribution. If the data is normally distributed, 
it can then be analyzed using the Pearson correlation test to show a relationship between variables.

\section{RESULT}

Overview of the HDI in East Java Province in 2019

Table 1. HDI in East Java Province in 2019

\begin{tabular}{lc}
\hline $\begin{array}{c}\text { Name of Regency or } \\
\text { City }\end{array}$ & $\begin{array}{c}\text { HDI } \\
\text { (Percent) }\end{array}$ \\
\hline Pacitan Regency & 68.16 \\
Ponorogo Regency & 70.56 \\
Trenggalek Regency & 69.46 \\
Tulungagung Regency & 72.62 \\
Blitar Regency & 70.57 \\
Kediri Regency & 71.85 \\
Malang Regency & 70.35 \\
Lumajang Regency & 65.33 \\
Jember & 66.69 \\
Banyuwangi Regency & 70,60 \\
Bondowoso Regency & 66.09 \\
Situbondo Kabupaten & 67.09 \\
Probolinggo Regency & 65,60 \\
Pasuruan Regency & 68.29 \\
Sidoarjo Regency & 80.05 \\
Mojokerto Regency & 73.53 \\
Jombang Regency & 72.85 \\
Nganjuk Regency & 71.71 \\
Madiun Regency & 71.69 \\
Magetan Regency & 73.49 \\
Ngawi Kabupaten & 70.41 \\
Bojonegoro Regency & 68.75 \\
Tuban District & 68.37 \\
Lamongan Regency & 72.57 \\
Gresik Kabupaten & 76.10 \\
Bangkalan Regency & 63.79 \\
Sampang Regency & 61.94 \\
Pamekasan Regency & 65.94 \\
Sumenep Regency & 66.22 \\
Kediri City & 78.08 \\
Blitar City & 78.56 \\
Malang city & 81.32 \\
Probolinggo City & 73.27 \\
Pasuruan City & 75.25 \\
Mojokerto City & 77.96 \\
Madiun City & 80.88 \\
City of Surabaya & 82.22 \\
Stone Town & 75.88 \\
East Java & 71.50 \\
\hline Sorce: Centran Bus &
\end{tabular}

Source: Central Bureau of Statistics
Table 1 above shows that the HDI value in East Java Province in 2019 was 71.50. The highest development index in East Java was achieved by the City of Surabaya with a HDI value of 82.22. In addition to the City of Surabaya, other districts/cities with high HDI are Malang City and Madiun City with HDI values of 81.32 and 80.88 respectively. Meanwhile, the regency/city in East Java Province with the lowest HDI was the Sampang Regency with a HDI value of 61.94. Other regencies/cities with low HDI values are the Bangkalan Regency with a HDI value of 63.79 and Probolinggo Regency with a HDI value of 65.60 .

\section{Normality Test Results}

Before using the correlation test of Pearson, the assumption that must be fulfilled is the normality test. This study employs the Shapiro-Wilk test because the research sample is in the form of the number of districts/cities in East Java, and this is less than 50. It is hoped that after the results of the normality test are obtained, the Pearson correlation test can then be conducted to determine the relationship between variables in this study.

Table 2. Normality test

\begin{tabular}{lc}
\hline \multicolumn{1}{c}{ Variable } & P \\
\hline $\begin{array}{l}\text { Human Development } \\
\text { Index }\end{array}$ & 0.410 \\
$\begin{array}{l}\text { Decent Drinking Water } \\
\text { Quality }\end{array}$ & 0.999 \\
Access to Adequate & 0.717 \\
Drinking Water & \\
Eligible latrines & 0.727 \\
Healthy Home & 1.071 \\
Eligible Public Places & 0.946 \\
\hline
\end{tabular}

Based on the test results, the significant values for HDI, decent water quality, access to proper drinking water, latrines, and healthy homes and TTU that meet the requirements are $0.410,0.999$, $0.717,0.727,1.071$, and 0.946 , respectively. All variables meet the criteria because a significant value of $>0.05$ means that the data is normally distributed, so the conditions can be met. 
Table 3. Pearson Correlation Analysis

\begin{tabular}{clcc}
\hline Variable & \multicolumn{1}{c}{ Variable } & P & $\begin{array}{c}\text { Pearson } \\
\text { correlation }\end{array}$ \\
\hline \multirow{2}{*}{ Human } & Decent Drinking Water Quality & 0.821 & -0.038 \\
Development & Access to Adequate Drinking Water & 0.000 & 0.690 \\
Index & Eligible latrines & 0.000 & 0.579 \\
& Healthy Home & 0.004 & 0.454 \\
& Eligible Public Places & 0.003 & 0.467 \\
\hline
\end{tabular}

\section{Relationship Analysis Results}

\section{The Relationship of Adequate Drinking Water Quality with the HDI}

Based on the results of the relationship analysis, the significant value calculated is 0.821 , and as the significant value is $>0.05$, this suggests that the quality of decent drinking water and the HDI are unrelated. The R-value (Pearson correlation coefficient) for the relationship between the quality of drinking water and the HDI is -0.038 , and this indicates a negative correlation between the variables. Therefore, even if every house has drinking water of decent quality, it will not necessarily increase the value of the HDI.

\section{The Relationship between Access to Adequate Drinking Water and the HDI}

Based on the results of the relationship analysis, the significant value calculated is 0.000 , this indicates that there is a relationship between access to adequate drinking water and the HDI. The R-value (Pearson correlation coefficient) of the relationship between access to adequate drinking water and the HDI is 0.690 , which means that the correlation is strong. A positive sign on the Pearson correlation means that the correlation between access to adequate drinking water and the HDI is unidirectional. Therefore, if a household has good access to proper and clean drinking water, the value of the HDI will also increase.

\section{The Relationship of Eligible Toilets with the HDI}

Based on the results of the relationship analysis, the significant value calculated is 0.000 , this indicates that there is a relationship between latrines that meets requirements with the HDI. The R-value (Pearson correlation coefficient) for the relationship between latrines that meet requirements and the HDI is 0.579 , this means that the resulting relationship is quite strong. The positive sign on the Pearson correlation concludes that the correlation between latrines that meets requirements and the HDI is unidirectional. Thus, if households use healthy and clean latrines, the value of the HDI will also increase.

\section{The Relationship Between Healthy Homes and the HDI}

Based on the results of the relationship analysis, the significant value calculated is at 0.004 , as the value is $<0.05$, this indicates that there is a relationship between healthy homes and the HDI. The R-value for the relationship between healthy homes and the HDI is also 0.454 , which means that the resulting correlation is quite strong. The positive symbol in the Pearson correlation means that the relationship between Healthy Homes and the Human Development Index is unidirectional. This means if a household meets the requirements of a healthy home, the value of the HDI will also increase.

\section{The Relationship between Eligible Public Places with the HDI}

Based on Table. 3, the significant value calculated is 0.003 and this suggests that there is a relationship between eligible public places and the HDI. The R-value (Pearson correlation coefficient) for the relationship between eligible public places and the HDI is 0.467 , this means that the resulting correlation is quite strong. The positive sign of the Pearson correlation concludes that the correlation etween eligible public places and the HDI is unidirectional. Thus, if individuals in a household conduct activities in public places that meet requirements, the value of the HDI will also increase. 


\section{Determinant Factors of the HDI}

Table. 3 shows that the factors related to the HDI are access to proper drinking water, clean latrines, healthy houses, and public places that meet requirements. The most strongly related factor is access to proper drinking water with a correlation value of 0.690 .

\section{DISCUSSION}

\section{The Relationship between Adequate Drinking Water Quality and the HDI}

This study found that there is no relationship between proper drinking water quality and the HDI. This could be due to the mandatory parameters that have been met in the requirements for proper drinking water quality. According to the Ministry of Health, based on existing regulations, there are two required parameters, namely mandatory and additional parameters; mandatory parameters are directly related to health but additional parameters are not directly related. For instance, mandatory parameters are microbiological and organic chemical parameters while examples of additional parameters are physical and chemical parameters (Ministry of Health, 2010).

In addition to the parameters, there are also differences in the community with regards to treating drinking water. For example, if someone has diarrhea, it may not be necessarily caused by consuming uncooked water. This is because human beings can form antibodies from consuming water without boiling it first, and more antibodies are produced with further consumption of the water (Zulkifli et al., 2017). Therefore, proper drinking water is not necessarily related to the HDI.

\section{The Relationship between Access to Adequate Drinking Water and the HDI}

Infectious diseases such as diarrhea, cholera, typhus and skin diseases can be caused by inadequate access to proper drinking water. This impacts public health and affects the life expectancy of community members (Azhar, et al., 2014). Previous research has also found that there is a positive correlation between the HDI and access to proper drinking water both in rural and urban areas (Riahi et al., 2018).

Therefore, to increase health values, promotive and preventive efforts to raise public awareness of healthy living behavior should be conducted. The results of which will be more effective in suppressing the occurrence of diseases and other health disorders (Sudana, 2018). According to Kustanto (2015), Indonesia is a middle-income country, which means that access to drinking water and sanitation is still low and this will affect the value of life expectancy. Moreover, if the AHH is low, it will also have a negative impact on the HDI value.

\section{The Relationship between Eligible Toilets and the HDI}

Proper and clean latrines in every household will indirectly contribute to the health of the latrine user. Automatically, this relates to the person's life expectancy. This can be seen from the incidence of diarrhea in an area, as bacteria that spread infection can be spread through fecal-oral transmission (Rahman et al., 2016). Moreover, the cause of diarrhea is $E$-coli bacteria and these bacteria are ever present in polluted waters. Therefore, it is important for individuals to know and have access to use appropriate latrines so that feces are disposed of appropriately and do not become a source of the transmission of diseases. Thus, if the latrine used meets requirements, the incidence of diarrhea can be prevented and the HDI will automatically increase (Rohmah and Syahrul, 2017).

\section{The Relationship between Healthy Homes and the HDI}

A healthy home is an important factor for human health. As such, the amount of time a homeowner spends at home will also have a considerable influence on his or her health. According to the Ministry of Health, there are 12 indicators of healthy homes. They include family planning program, maternal delivery service facilities, complete basic immunisations, toddlers receiving growth monitoring, standardized treatment for tuberculosis sufferers, routine treatment for diabetics, appropriate treatment for mental disorders, non-smoking behavior in every home, ownership of national health insurance, access to clean water facilities, and healthy latrine facilities in every household (Ministry of Health, 2017).

Another study states that the increase in $\mathrm{AHH}$ can be influenced by the visible characteristics of drinking water, the 
affordability of clean drinking water, the ownership of latrines in every household, and households that meet housing requirements (Anggraini and Umi, 2013).

\section{The Relationship between Eligible Public Places and the HDI}

Markets, mosques, shopping malls, terminals, and transport stations are public places that we often encounter in society. Community interaction and disease transmission are also greater in these places. If these places are not maintained to follow health requirements, it is feared that diseases will easily spread from one individual to another. Therefore, there are requirements set by the Minister of Health for existing sanitation facilities within the community (Marinda and Ardillah, 2019).

Health problems that arise from public places such as transportation terminals are caused by the lack of proper sanitation facilities in the terminal, including toilets or bathrooms that are not kept clean so much so that they become a source of disease transmission for everyone in the terminal. Furthermore, contact with public facilities contaminated with pathogens can be a contributing factor to disease infection for individuals (Ramlal et al., 2019). If sanitation in public places is unsatisfactory, many diseases can be transmitted, thus decreasing life expectancy and impacting the HDI (Istiqomah, 2015).

\section{CONCLUSIONS AND SUGGESTIONS}

\section{Conclusions}

Environmental factors are closely related to the Human Development Index. This research found that there is a relationship between access to proper drinking water, proper latrines, healthy houses, and public places that meet the requirements of the HDI. Only one variable showed no relationship with the HDI, and it is the variable of decent drinking water quality. In addition, the largest correlation value between an environmental factor with the HDI is access to proper drinking water.

\section{Suggestions}

Effective and targeted programs are urgently needed to solve basic sanitation problems, including training programs for drinking water filtration and healthy latrine awareness. The hope is that the HDI in low HDI areas can slowly increase with such programs within the community.

Commitment from the government is important so that the programs can run effectively. The East Java Provincial Health Office should play a role for the success of the programs. Cross-sectoral support and cooperation are required, especially from The Regional Government and local PDAMs in improving the accessibility of clean water as it is a factor that is closely related to the Human Development Index. The drawback of this research is that the influence between environmental factors and the HDI has not been explored. Further research should thus be conducted to examine links of the HDI with other environmental factors by using appropriate statistical measures.

\section{REFERENCES}

Anggraini, E. dan Umi, L., 2013. Disparitas Spasial Angka Harapan Hidup di Indonesia Tahun 2010. Jurnal Bumi Indonesiaumi Indonesia, 3(2), pp.7180.

Azhar, K., Dharmayanti, I. dan Anwar, A., 2014. Pengaruh Akses Air Minum Terhadap Kejadian Penyakit Tular Air (Diare dan Demam Tifoid). Buletin Penelitian Sistem Kesehatan, 17(29), pp.107-114.

Blum, H.L., 1974. Planning for Health: Development and Application of Social Change Theory.

Central Bureau of Statistics , 2019. Indeks Pembangunan Manusia Menurut Kabupaten/Kota [Metode Baru], 20102019.

Danasari, L.S. dan Wibowo, A., 2017. Analisis Angka Harapan Hidup di Jawa Timur Tahun 2015. Jurnal Biometrika dan Kependudukan, 6(1), pp.17-25.

Devy, S., R. Nadhiroh, S., D. Rahmayanti, R. dan Martini, S., 2017. Gambaran Sarana Air Bersih dan Jamban Keluarga di Daerah Tertinggal

Kabupaten Sampang. IPTEK Journal of Proceedings Series, 3(5), pp. 5-10.

Dwiningtias, Y, D, P dan Mahmudah, 2019. Analisis Regresi Ordinal Model Logit 
Untuk Mengidentifikasi Faktor yang Mempengaruhi Indeks Pembangunan Manusia. Jurnal Biometrika dan Kependudukan, 8(2), pp.174-182.

Istiqomah, N., 2015. Gambaran Kondisi Fasilitas Sanitasi Terminal Regional Daya di Kota Makassar. Diss. Universitas Islam Negeri Alauddin Makassar.

Kustanto, D.N., 2015. Dampak Akses Air Minum dan Sanitasi Terhadap Peningkatan Kesejahteraan. Jurnal Sosek Pekerjaan Umum, 7(3), pp.173180.

Marinda, D. dan Ardillah, Y., 2019. Implementasi Penerapan Sanitasi Tempat-tempat Umum Pada Rekreasi Benteng Kuto Besak Kota Palembang. Jurnal Kesehatan Lingkungan Indonesia, 18(2), p.89.

Marwah, U., 2017. Analisis Pemenuhan Kebutuhan Air. Diss. Institut Teknologi Sepuluh Nopember Surabaya.

Ministry of Health of the Republic Indonesia, 2010. Peraturan Menteri Kesehatan Republik Indonesia Nomor 492/Menkes/Per/IV/2010 Tentang Persyaratan Kualitas Air Minum. Peraturan Mentri Kesehatan Republik Indonesia.

Ministry of Health of the Republic Indonesia, 2017. Program Indonesia Sehat dengan Pendekatan Keluarga. www.kemkes.go.id.

Muda, R., Koleangan, R. dan Kalangi, J.B., 2019. Pengaruh Angka Harapan Hidup, Tingkat Pendidikan Dan Pengeluaran Perkapita Terhadap Pertumbuhan Ekonomi Di Sulawesi Utara Pada Tahun 2003-2017. Jurnal Berkala Ilmiah Efisiensi, 19(01), pp.44-55.

Putri, N.M.C.R., Asmara, I.W.S. dan Sudiadnyana, I.W., 2018. Tinjauan Keadaan Sanitasi Pasar di Pasar Umum Kusamba Kecamatan Dawan Kabupaten Klungkung Tahun 2018. Jurnal Kesehatan Lingkungan, 8(2), pp.70-77.

Rahman, H.F., Widoyo, S., Siswanto, H. dan Biantoro, 2016. Faktor-Faktor Yang Berhubungan Dengan Kejadian Diare di Desa Solor Kecamatan Cermee Bondowoso. Nurseline Journal, 1(1), p.3.

Ramlal, P.S., Stenström, T.A., Munien, S.,
Amoah, I.D., Buckley, C, A. dan Sershen, 2019. Relationships Between Shared Sanitation Facilities and Diarrhoeal and Soil-Transmitted Helminth Infections: An Analytical Review. Journal of Water Sanitation dan Hygiene for Development, 9(2), pp.198-209.

Riahi, M., Mohammadi, A.A., Moghadam, V.K., Robati, Z.S. dan Bidkhori, M., 2018. Diarrhea Deaths in Children Among Countries with Different Levels of The Human Development Index. Data in Brief. 17, pp.954-960.

Rohmah, N. dan Syahrul, F., 2017. Hubungan Kebiasaan Cuci Tangan dan Penggunaan Jamban Sehat Dengan Kejadian Diare Balita. Jurnal Berkala Epidemologi, 5(1), pp.95-106.

Sari, U., Harianto dan Falatehan, A.F., 2016. Strategi Meningkatkan Angka Harapan Hidup (AHH) Melalui Alokasi Anggaran Kesehatan di Provinsi Jawa Barat. Jurnal Manajemen Pembangunan Daerah, 8(1), pp. 29-41.

Siswati, E. dan Hermawati, D.T., 2018. Analisis Indeks Pembangunan Manusia (IPM) Kabupaten Bojonegoro. Jurnal Ilmiah Sosio Agribis 18(2), pp. 93-114.

Sudana, I.W., 2018. Gerakan Masyarakat Hidup Sehat Dalam Mencegah Terjadinya Penyakit Gigi dan Mulut. Jurnal Kesehatan Gigi, 6(1), pp. 430-439.

Sugiantari, A, P, dan Budiantara, I, N., 2013. Analisis Faktor-faktor yang Mempengaruhi Angka Harapan Hidup di Jawa Timur Menggunakan Regresi Semiparametrik Spline. Jurnal Sains dan Seni ITS, 2(1), pp. D37-D41.

Suwita, K., Syafri, M. dan Fahri, S., 2019. Analisis Determinan Rumah Sehat dalam Mendukung Pembangunan Berwawasan Lingkungan di Kelurahan Kebun Hdanil Kota Jambi Suwita, Muhammad Syafri dan Sukmal Fahri. Jurnal Pembangunan Berkelanjutan, 2(1), pp.60-73.

Syahrir, S., Syamsul, M., Aswadi, Surahmati dan Aeni, S., 2019. Faktor - Faktor yang Berhubungan dengan Kepemilikan Jamban Keluarga di Wilayah Kerja Puskesmas Pertiwi Kota Makassar. Higiene, 5(1), pp. 52-59.

Yektiningsih, E., 2018. Analisis Indeks Pembangunan Manusia (IPM) 
Kabupaten Pacitan Tahun 2018. 18(2), pp. 32-50.

Zuhairoh, Z,. A. dan Melaniani, S. 2017. Pengaruh Angka Kematian Bayi, Angka Partisipasi Murni, Rasio Ketergantungan Terhadap Indeks Pembangunan Manusia Provinsi Jawa Timur. Jurnal Biometrika dan Kependudukan, 7(1), pp. 87-95.

Zulkifli, A., Rahmat, K.B. dan Ruhban, A., 2017. Analisis Hubungan Kualitas Air Minum dan Kejadian Diare di Wawondula Sebagai Wilayah Pemberdayaan PT. Vale Sorowako. Jurnal Kesehatan Lingkungan Politeknik Kesehatan Makassar, 12(1), p.50. 